\title{
SOIL ORGANIC MATTER AS A FUNCTION OF NITROGEN FERTILIZATION IN CROP SUCCESSIONS
}

\author{
Renato Yagi1 ; Manoel Evaristo Ferreira ${ }^{1 *}$; Mara Cristina Pessôa da Cruz ${ }^{1}$; José Carlos Barbosa²; \\ Luiz Alberto Navarro de Araújo ${ }^{1}$ \\ ${ }^{1}$ UNESP/FCAV - Depto. de Solos e Adubos, Via de Acesso Prof. Paulo Donato Castellane s/no - 14884-900 - \\ Jaboticabal, SP - Brasil. \\ ${ }^{2}$ UNESP/FCAV - Depto. de Ciências Exatas. \\ *Corresponding author <evaristo@fcav.unesp.br>
}

\begin{abstract}
The interdependence between the $\mathrm{C}$ and $\mathrm{N}$ cycles is reflected by the levels of soil organic matter (SOM). SOM and organic C levels in water soluble (C-WS) humic acids (C-HA), fulvic acids (C-FA), and humin fractions $(\mathrm{C}-\mathrm{H})$ were evaluated through the classic chemical fractionation method in samples of a Rhodic Eutrudox from a randomized blocks experimental design, with split-split-plots using five nitrogen sidedressing levels for corn $\left(0 ; 60 ; 120 ; 180\right.$; and $\left.240 \mathrm{~kg} \mathrm{ha}^{-1} \mathrm{~N}\right)$ as the main treatment, two crop sequences (corn-corn and soybean-corn) as the secondary treatment, and two sampling depths (0 to 0.2 and 0.2 to $0.4 \mathrm{~m}$ ) as a sub-subtreatment. Nitrogen fertilization did not affect SOM levels, but favored the synthesis of substances in the C-HA fraction. There was a quadratic effect of $\mathrm{N}$ rates on the C-WS and C-FA levels in the corn-corn succession. The soybean-corn succession resulted in larger SOM and organic C levels in the C-H fraction. Key words: humic acids, humin, urea, corn, soybean
\end{abstract}

\section{MATÉRIA ORGÂNICA DO SOLO EM FUNÇÃO DE ADUBAÇÃO NITROGENADA EM SUCESSÕES DE CULTURAS}

\begin{abstract}
RESUMO: A interdependência dos ciclos de $\mathrm{C}$ e $\mathrm{N}$ reflete-se nos teores de matéria orgânica do solo (MOS). Em um delineamento experimental em blocos casualizados, com parcelas sub-subdivididas, tendo como tratamento principal cinco doses de nitrogênio de cobertura na cultura do milho $\left(0 ; 60 ; 120 ; 180\right.$ e $240 \mathrm{~kg} \mathrm{ha}^{-1}$ de $\mathrm{N}$ ), como tratamento secundário, as sucessões milho-milho e soja-milho, e como sub-subtratamento, duas profundidades de amostragem ( 0 a 0.2 e 0.2 a $0.4 \mathrm{~cm}$ ), avaliaram-se os teores de MOS e de C orgânico nas frações solúvel em água (C-SA), ácidos húmicos $(\mathrm{C}-\mathrm{AH})$, ácidos fúlvicos $(\mathrm{C}-\mathrm{AF})$ e humina $(\mathrm{C}-\mathrm{H})$, por meio do método clássico de fracionamento químico, em um Latossolo Vermelho eutrófico, de textura argilosa. A adubação nitrogenada não afetou os teores de MOS, mas favoreceu a síntese de compostos da fração C-AH. Houve efeito quadrático das doses de $\mathrm{N}$ nos teores de C-SA e de C-AF na sucessão milho-milho. A sucessão soja-milho resultou em maiores teores de MOS e de C orgânico na fração humina.

Palavras-chave: ácidos húmicos, humina, uréia, milho, soja
\end{abstract}

\section{INTRODUCTION}

Amendment with organic residues is a longstanding practice to increase or preserve soil organic matter (SOM). Efforts have also been made to demonstrate that productivity increases due to mineral fertilization are sufficient to maintain SOM because of the incorporation of crop residues (Kiehl, 1985). Some of the practices that may increase SOM contents are: establishment of pastures, reduced soil tillage, and adoption of crop rotation schemes with the inclusion of species that yield a great amount of residues, among others (Bayer \& Mielniczuk, 1999). Decreased SOM is related to the use of inadequate agricultural management systems, and could be the result of low fertility, low production of residues, excess tillage, and accelerated erosion; insisting on this error may render the system unfeasible from an eco- nomic or environmental point of view (Mielniczuk, 1999).

In rotation systems, the cultivation of legumes may increase SOM contents directly by the addition of $\mathrm{C}$ from plant tissues, or indirectly, by changing their quality and turnover, as well as by affecting the amount of residues produced by the subsequent crop, due to the incorporation into the soil of symbiotically-fixed N (Cadish et al., 1998). It is also known that soil $\mathrm{C}$ and $\mathrm{N}$ contents, either organic or total, decrease as soybean cultivation frequency increases in crop rotation systems, as a consequence of the low amount of residues yielded by the crop (Havlin et al., 1990; Varvel, 1994) and because of the $\mathrm{N}$ exported in the grain (Havlin et al., 1990). These results may not be entirely applicable to Brazilian conditions, since studies targeted at the selection of strains, aiming to maximize the biological fixation of $\mathrm{N}$ by soybean, en- 
sure greater amounts of $\mathrm{N}$ in the grain and total $\mathrm{N}$ accumulated by the plants, as compared to other countries (Vargas \& Hungria, 1997).

Similarly to the use of legumes in cropping systems, nitrogen sidedressing fertilization in annual crops such as corn can also be responsible for increased SOM contents, by increasing the amount of crop residues that return to the soil (Liang et al., 1998). In an experiment conducted for eight years in the USA, Varvel (1994) verified that the increases in SOM contents with monoculture soybean or with soybean in rotation with either corn or sorghum were smaller than the increases obtained due to nitrogen sidedressing in corn or sorghum monocultures.

The comparisons between corn production systems, either as a monoculture or in rotation with soybean, fertilized or not with $\mathrm{N}$, can be extended to SOM quality, represented by the humic acids, fulvic acids, and humin fractions. Under reduced soil tillage, Nascimento et al. (1991) observed that corn grown in rotation with soybean had about $27 \%$ more $\mathrm{C}$ in the humic acids fraction than in monoculture corn. In the no-till system, Sousa \& Melo (2003) observed higher C contents in the fulvic acids fraction when growing corn in rotation with soybean, as compared with monoculture corn. With regard to nitrogen fertilization, Tan et al. (1972) observed increased $\mathrm{C}$ contents in the humic acids fraction with variable $\mathrm{N}$ doses.

The humic acids, fulvic acids, and humin fractions, obtained by means of chemical fractionation, possess peculiar characteristics that qualify SOM under several aspects. Among these characteristics, it is worth noting the great number of acid groupings in the humic and fulvic acids fractions, largely responsible for soil cation exchange and acid-base buffering capacities (MacCarthy, 2001), and the association of compounds in the humin fraction with soil mineral colloids, which impart resistance to biodegradation (Rice, 2001).

This work had the objective of evaluating the effects of nitrogen sidedressing in corn when grown after previous cultivations with corn or soybean, on the amount and quality of the produced SOM.

\section{MATERIAL AND METHODS}

The experiment was carried out on a clayey-textured (590 $\mathrm{g} \mathrm{kg}^{-1}$ clay, $210 \mathrm{~g} \mathrm{~kg}^{-1}$ silt and $200 \mathrm{~g} \mathrm{~kg}^{-1}$ sand)
Rhodic Eutrudox, in a center pivot irrigated area in Morro Agudo, SP, Brazil ( $\left.20^{\circ} 40^{\prime} \mathrm{S}, 48^{\circ} 15^{\prime} \mathrm{W}\right)$. The climate of the region, according to Köppen's classification, is AW (tropical with a rainy summer, dry winter, and mean temperature in the coolest month higher than $18^{\circ} \mathrm{C}$ ). Oliveira \& Prado (1987) classified the water and thermal regimes as udic and epithermal, respectively.

At a stage prior to the proper experiment, the area was tilled by means of a scarification with a five-shank scarifier, down to a depth of $30 \mathrm{~cm}$, followed by one harrowing with a 20-disk harrow and two harrowings with a 44-disk leveling harrow. Following tillage, cultivations were made with corn (October 1998 to February 1999), bean (April to August 1999), and corn (September 1999 to February 2000). Then, the entire area was sampled at soil layers from 0 to 20,20 to 40 , and 40 to $60 \mathrm{~cm}$, and 20 cores were collected from each layer in order to form a composite sample. The soil chemical analysis (Raij et al., 1987) is presented in Table 1 .

Five nitrogen sidedressing rates were evaluated in corn as the main treatment in the plots, with two crop successions as the secondary treatment in the subplots and two depths as sub-subtreatments, in a split-split plot random block design with four replicates. In the secondary treatments, the two crop successions consisted of corn grown after corn (C-C) and corn grown after soybean (S$\mathrm{C})$. In the main treatment, $\mathrm{N}$ sidedressing was applied during the last corn cultivation, at rates of $0 ; 60 ; 120 ; 180$; and $240 \mathrm{~kg} \mathrm{ha}^{-1}$, as urea. The $\mathrm{N}$ sidedressing doses were applied at 14;30;46; and 57 days after emergence, when plants had $4 ; 8$; or 12 leaves, and at tasseling, respectively. The sub-subplots consisted of soil layers from 0 to $20 \mathrm{~cm}$ and 20 to $40 \mathrm{~cm}$.

By the time the secondary treatments were established, the soybean was sown before the corn (March and May 2000, respectively), in order to avoid corn shading over the soybean. After harvest, the soybean and corn plants were cut just above soil surface and chopped with a rotary hoe. Crop stubble incorporation was performed at tillage, by means of scarification and level harrowing, which, according to Bayer \& Mielniczuk (1997), characterize reduced tillage. In October 2000, corn was sown as a last crop in all subplots. After harvesting this last corn crop, the soil from each sub-subplot was sampled in accordance to the procedure adopted for the initial soil sampling.

Table 1 - Soil chemical analysis for the experimental area (February 2000).

\begin{tabular}{|c|c|c|c|c|c|c|c|c|c|c|}
\hline Depth. & $\mathrm{P}$ & $\mathrm{SOM}^{*}$ & $\mathrm{pH} \mathrm{CaCl}_{2} 0.01 \mathrm{~mol} \mathrm{~L}^{-1}$ & $\mathrm{~K}^{+}$ & $\mathrm{Ca}^{2+}$ & $\mathrm{Mg}^{2+}$ & $\mathrm{H}+\mathrm{Al}$ & SB & CEC & $\mathrm{V}$ \\
\hline $\mathrm{cm}$ & $\mathrm{mg} \mathrm{dm} \mathrm{dm}^{-3}$ & $\mathrm{~g} \mathrm{dm}^{-3}$ & & $-\ldots$ & ---- & $-\cdots m$ & $1_{c} \mathrm{dm}^{-3}$ & $-\cdots$ & - & $\%$ \\
\hline $0-20$ & 92 & 23 & 5.9 & 2.8 & 43 & 12 & 25 & 58 & 83 & 70 \\
\hline $20-40$ & 9 & 19 & 5.1 & 1.0 & 16 & 5 & 38 & 22 & 60 & 37 \\
\hline $40-60$ & 5 & 16 & 5.2 & 1.0 & 17 & 4 & 31 & 22 & 53 & 42 \\
\hline
\end{tabular}

*SOM = soil organic matter 
At the end of the experiment, SOM fractionation and $\mathrm{C}$ determination in the organic fractions were performed for the soil samples of the 0 to 20 and 20 to 40 $\mathrm{cm}$ layers, according to methods described in Yagi et al. (2003). The SOM was fractionated according to its solubility in alkaline and acid media, with sodium hydroxide and sulfuric acid. $\mathrm{C}$ in the organic fractions was obtained by sulfochromic digestion and quantified by colorimetry. The organic matter fractions determination included: water-soluble organic carbon (C-WS), humic substances (CHS), fulvic acids (C-FA), humic acids (C-HA), and hu$\min (\mathrm{C}-\mathrm{H})$. The results were submitted to analysis of variance and the means were then compared (Tukey at $5 \%$ ). The $\mathrm{N}$ dose effects were analyzed by polynomial regression.

\section{RESULTS AND DISCUSSION}

The soybean-corn succession presented higher SOM contents $(P<0.01)$ than the corn-corn succession, with a significant effect of the interaction between crop successions and sampling depths (Table 2). When the ef- fects of this interaction are partitioned (Figure 1), the difference between SOM contents in both crop successions was restricted to the depth from 0 to $20 \mathrm{~cm}$, where the soybean-corn succession was higher than the corn-corn succession by about $2 \mathrm{~g} \mathrm{dm}^{-3}(P<0.05)$.

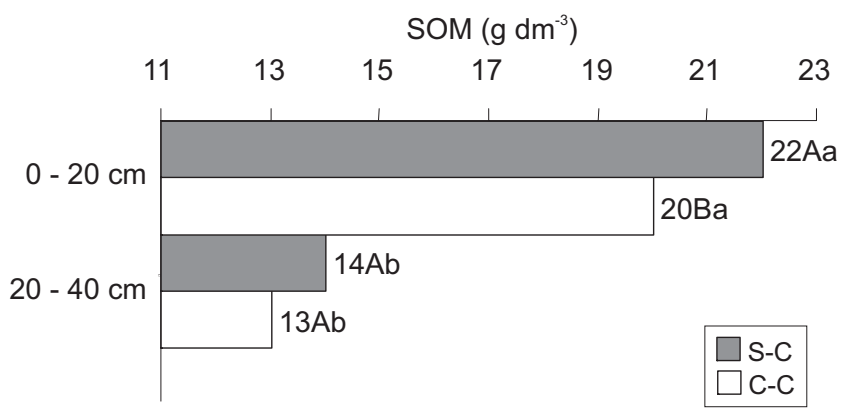

Figure 1 - Breakdown of interactions between corn-corn (C-C) and soybean-corn (S-C) successions, and sampling depths, on soil organic matter (SOM) contents. Identical upper-case letters between crop successions at the same depths, and lower-case letters between depths at the same crop succession, indicate the absence of significant effect by the Tukey test at $5 \%$.

Table 2 - Soil organic matter (SOM) and organic $\mathrm{C}$ in the organic fractions, after nitrogen sidedressing and in corn-corn (CC) and soybean-corn (S-C) successions.

\begin{tabular}{|c|c|c|c|c|c|c|}
\hline $\mathrm{N}$ Rate $(\mathrm{N})$ & SOM & $\mathrm{C}-\mathrm{WS}^{1}$ & $\mathrm{C}-\mathrm{HS}$ & C-HA & C-FA & $\mathrm{C}-\mathrm{H}$ \\
\hline $\mathrm{kg} \mathrm{ha}^{-1}$ & $-\cdots-1-n-1$ & 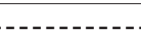 & 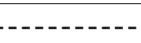 & $n^{-3}-\ldots-\ldots-1$ & $-\ldots \ldots$ & - \\
\hline 0 & $18 \mathrm{a}$ & $0.05 \mathrm{a}$ & $2.59 \mathrm{a}$ & $1.20 \mathrm{~b}$ & $1.38 \mathrm{a}$ & $7.62 \mathrm{a}$ \\
\hline 60 & $17 \mathrm{a}$ & $0.06 \mathrm{a}$ & $2.55 \mathrm{a}$ & $1.29 \mathrm{ab}$ & $1.30 \mathrm{a}$ & $7.35 \mathrm{a}$ \\
\hline 120 & $17 \mathrm{a}$ & $0.10 \mathrm{a}$ & $2.74 \mathrm{a}$ & $1.36 \mathrm{ab}$ & $1.37 \mathrm{a}$ & $7.28 \mathrm{a}$ \\
\hline 180 & $17 \mathrm{a}$ & $0.09 \mathrm{a}$ & $2.67 \mathrm{a}$ & $1.45 \mathrm{a}$ & $1.18 \mathrm{a}$ & $6.77 \mathrm{a}$ \\
\hline 240 & $17 \mathrm{a}$ & $0.10 \mathrm{a}$ & $2.54 \mathrm{a}$ & $1.49 \mathrm{a}$ & $1.11 \mathrm{a}$ & $7.33 \mathrm{a}$ \\
\hline F Test & $0.59 \mathrm{~ns}$ & $3.17 \mathrm{~ns}$ & $0.46 \mathrm{~ns}$ & $5.08^{*}$ & $1.94 \mathrm{~ns}$ & $0.82 \mathrm{~ns}$ \\
\hline Msd (5\%) & 3.61 & 0.057 & 0.46 & 0.23 & 0.38 & 1.55 \\
\hline CV (\%) & 15.53 & 63.73 & 15.57 & 15.38 & 26.91 & 18.91 \\
\hline \multicolumn{7}{|c|}{ Crop Successions (CS) } \\
\hline $\mathrm{C}-\mathrm{C}$ & $17 \mathrm{~b}$ & $0.07 \mathrm{a}$ & $2.66 \mathrm{a}$ & $1.39 \mathrm{a}$ & $1.27 \mathrm{a}$ & $6.88 \mathrm{~b}$ \\
\hline $\mathrm{S}-\mathrm{C}$ & $18 \mathrm{a}$ & $0.08 \mathrm{a}$ & $2.58 \mathrm{a}$ & $1.33 \mathrm{a}$ & $1.25 \mathrm{a}$ & $7.66 \mathrm{a}$ \\
\hline F Test & $18.27 * *$ & $4.36 \mathrm{~ns}$ & $4.11 \mathrm{~ns}$ & $4.15 \mathrm{~ns}$ & $0.03 \mathrm{~ns}$ & $21.51 * *$ \\
\hline Msd (5\%) & 0.63 & 0.013 & 0.14 & 0.07 & 0.14 & 0.35 \\
\hline CV (\%) & 7.74 & 34.20 & 11.39 & 10.75 & 23.71 & 10.22 \\
\hline \multicolumn{7}{|l|}{ Depth (Dp) } \\
\hline $0-20 \mathrm{~cm}$ & $21 \mathrm{a}$ & $0.09 \mathrm{a}$ & $2.95 \mathrm{a}$ & $1.60 \mathrm{a}$ & $1.35 \mathrm{a}$ & $9.03 \mathrm{a}$ \\
\hline $20-40 \mathrm{~cm}$ & $14 \mathrm{~b}$ & $0.07 \mathrm{~b}$ & $2.29 \mathrm{~b}$ & $1.12 \mathrm{~b}$ & $1.17 \mathrm{~b}$ & $5.51 \mathrm{~b}$ \\
\hline F Test & $696.20 * *$ & $12.47 * *$ & $174.86 * *$ & $217.82 * *$ & $18.11^{* *}$ & $455.84 * *$ \\
\hline Msd (5\%) & 0.57 & 0.01 & 0.10 & 0.06 & 0.11 & 0.33 \\
\hline CV (\%) & 7.25 & 27.34 & 8.36 & 10.62 & 18.83 & 7.39 \\
\hline \multicolumn{7}{|l|}{ Interactions } \\
\hline $\mathrm{N} \times \mathrm{CS}$ & $0.92 \mathrm{~ns}$ & $5.35 * *$ & $4.05^{*}$ & $16.97 * *$ & $3.48^{*}$ & $0.91 \mathrm{~ns}$ \\
\hline $\mathrm{N} \times \mathrm{Dp}$ & $2.00 \mathrm{~ns}$ & $2.42 \mathrm{~ns}$ & $0.29 \mathrm{~ns}$ & $3.01 *$ & $0.92 \mathrm{~ns}$ & $2.04 \mathrm{~ns}$ \\
\hline $\mathrm{CS} \times \mathrm{Dp}$ & $4.23 *$ & $3.20 \mathrm{~ns}$ & $0.28 \mathrm{~ns}$ & $0.81 \mathrm{~ns}$ & $0.19 \mathrm{~ns}$ & $3.99 \mathrm{~ns}$ \\
\hline $\mathrm{N} \times \mathrm{CS} \times \mathrm{Dp}$ & $0.75 \mathrm{~ns}$ & $0.17 \mathrm{~ns}$ & $2.39 \mathrm{~ns}$ & $0.61 \mathrm{~ns}$ & $1.86 \mathrm{~ns}$ & $1.65 \mathrm{~ns}$ \\
\hline Blocks & $0.42 \mathrm{~ns}$ & $0.47 \mathrm{~ns}$ & $3.53 *$ & $0.99 \mathrm{~ns}$ & $2.00 \mathrm{~ns}$ & $0.13 \mathrm{~ns}$ \\
\hline
\end{tabular}

ns, * and **: non-significant, significant at 5 and $1 \%$ probability, respectively; C: Carbon; WS: water-soluble fraction; HS: humic substances fraction; HA: humic acids fraction; FA: fulvic acids fraction; H: humin fraction; Msd: Minimum significant difference; CV: Coefficient of variation. 
The amount of residues yielded by soybean tops $\left(7,950 \mathrm{~kg} \mathrm{ha}^{-1}\right.$ dry matter) was lower than those of corn $\left(15,470 \mathrm{~kg} \mathrm{ha}^{-1}\right.$ dry matter) grown in the same season. In addition, there were about $136 \%$ more $\mathrm{N}$ in the dry matter of the soybean in relation to the dry matter of corn, which suggests that the legume residues undergo faster decomposition. Although root dry matter yield was not determined, these data were estimated from results obtained by Buyanovsky \& Wagner (1986), considering root: top ratios of 0.37 and 0.84 for soybean and corn, respectively, at the 0 to $20 \mathrm{~cm}$ depth. Thus, the theoretical dry matter yields for soybean and corn roots were about 2,940 and $12,990 \mathrm{~kg} \mathrm{ha}^{-1}$, respectively. With regard to dry matter yield in the tops of the last corn crop, the yield obtained after soybean was $278 \mathrm{~kg} \mathrm{ha}^{-1}$ higher than that obtained after corn. In long-term experiments, a greater input of crop residues (Havlin et al., 1990; Varvel, 1994; Bayer \& Mielniczuk, 1997) and lower soil tillage intensity (Bayer \& Mielniczuk, 1997) are decisive factors to increase SOM contents in cropping systems. However, based on the data presented, the input of organic residues into the soil was not the factor responsible for the higher SOM contents verified in the soybean-corn succession.

Considering the amounts of residues added by the soybean and corn crops and the short experimental period evaluated in the present study, it is believed that the chemical composition of the organic residues from these two crops was the factor responsible for the higher SOM contents in the soybean-corn succession. The chemical composition analysis conducted by Broder \& Wagner (1988) in the vegetative tops of soybean and corn plants corroborate this reasoning. Those authors observed that soybean and corn residues showed lignin concentrations of 119 and $56 \mathrm{~g} \mathrm{~kg}^{-1}$, respectively, that is, the soybean residues had approximately $113 \%$ more lignin than corn residues. Taking into account the dry matter yields for top plants, this would result in 945 and $866 \mathrm{~kg} \mathrm{ha}^{-1}$ lignin, respectively, for soybean and corn plots.

$\mathrm{N}$ concentrations $126 \%$ higher and, theoretically, lignin concentrations $113 \%$ higher would result in a greater amount of basic substrate for the formation of humus in the soybean-corn succession, according to the main humus synthesis pathway, among the four theories cited by Stevenson (1994). In this pathway, the polymerization of polyphenols from lignified sources to quinones, and the condensation of the latter with amino compounds, results in nitrogen polymers with complex structures and which are resistant to biodegradation, characteristically similar to compounds of the C-HA fraction. Although no difference was observed between C-HA contents in the corn-corn and soybean-corn successions (Table 2), the higher yield of humic compounds, associated with the clayey character of the soil under study (590 $\mathrm{g} \mathrm{kg}^{-1}$ clay), still explain the higher SOM contents in the soybean-corn succession. Compounds in the C-HA fraction can become complexed to mineral colloids and not be extracted with the alkaline solution, thus forming the humin fraction $(\mathrm{C}-\mathrm{H})$ of SOM (Hatcher et al., 1985; Rice 2001). This argument is supported by the fact that among the organic fractions, the only difference $(P<0.01)$ between crop successions was observed for $\mathrm{C}-\mathrm{H}$ contents, with an average value of about $13 \%$ between both soil depths (Table 2).

The C-H fraction represents compounds closely linked to soil mineral colloids; in addition to their charge density, relatively smaller than in other SOM humified fractions, the C-H fraction is highly cross-linked (Hayes \& Himes, 1986), which imparts to the SOM a high resistance to degradation, so that a vast variety of enzymes or a single highly-versatile enzyme are required for an effective mineralization process (Rice, 2001). Also, according to Mendonça \& Silva (2004), the mean residence time of organic compounds associated with the soil mineral fraction is positively correlated with the surface area of the minerals. At last, the greater SOM stability in the soybean-corn succession explains the greater SOM contents found in them. Sousa \& Melo (2003) did not observe differences in SOM and C-H contents between a biennial corn-fallow-soybean-fallow succession and an annual corn-fallow succession, after four years of study in conventional and no-till systems. Gregorich et al. (2001), using the ${ }^{13} \mathrm{C}$ solid-state nuclear magnetic resonance technique, observed greater amounts of aromatic $\mathrm{C}$ in soils of corn grown in rotation with legumes, in relation to monoculture corn, which suggests that a higher amount of compounds similar to or derived from lignin was supplied to the soil organic $\mathrm{C}$ in the first system.

In general, for both crop successions the $\mathrm{C}-\mathrm{H}$ fraction was predominant in the SOM, followed by compounds from the C-HA and C-FA fractions, which had similar percentages, and by the C-WS fraction (Figure 2). In Brazilian clayey-textured Oxisols, the major part of the SOM consists of the C-H fraction (Volkoff et al., 1978; Nascimento et al., 1991; Mendonça \& Rowell, 1994), while the proportion between the C-HA and C-FA fractions is variable, and a greater amount of C-FA is generally observed in relation to C-AH (Volkoff et al., 1978; Nascimento et al., 1991; Mendonça \& Rowell, 1994). In samples of a loamy-textured Typic Hapludox, Yagi et al. (2003) observed that the C-H fraction represented about $58 \%$ of SOM, and the C-HA fraction was predominant over the C-FA fraction. The higher $\mathrm{C}$ supplies found in more humified SOM fractions reflect the physical and chemical stability of organomineral complexes and of alkaline-soluble humic substances (Bayer et al., 2002).

The SOM contents, as well as the contents of the $\mathrm{C}$ organic fractions, were higher in the 0 to $20 \mathrm{~cm}$ layer, as compared with the 20 to $40 \mathrm{~cm}$ layer (Table 2). However, the reduction of SOM and $\mathrm{C}$ in the organic fractions 
was not proportional to depth increase. While there was a decrease of about $33 \%$ in SOM from the 0 to $20 \mathrm{~cm}$ layer to the 20 to $40 \mathrm{~cm}$ layer, the percentages of decrease of C-WS, C-HS, C-FA, C-HA, and C-H were about $22 \%, 22 \%, 17 \%, 30 \%$, and $37 \%$, respectively, in those layers. The differences in the amounts of C-HA and $\mathrm{C}-\mathrm{H}$ in the SOM between the evaluated depths could be associated with the synthesis of compounds that make up those fractions in the layer nearest to the surface, due to the constant additions of crop residues, both before and during the experimental period. On the other hand, the compounds in the C-FA fraction are less polymerized, have a smaller molecular weight and, mainly, greater reactivity than the compounds in the C-HA fraction, due to the higher number of carboxylic groupings that exist in their structures (Stevenson, 1994), favoring complexation with sesquioxides and silicates, and consequently the protection against microbial attack and maintenance in the system (Mendonça \& Rowell, 1994; Yagi et al., 2003).

A reduction was observed for the C-HA/C-FA ratio, from 1.18 at the 0 to $20 \mathrm{~cm}$ depth, to 0.96 at the 20 to $40 \mathrm{~cm}$ depth (Table 2), in a similar way as observed by Nascimento et al. (1991) and Mendonça \& Rowell (1994), who also studied the effects of cultivations on the SOM fractions. The HA/FA ratio usually decreases with

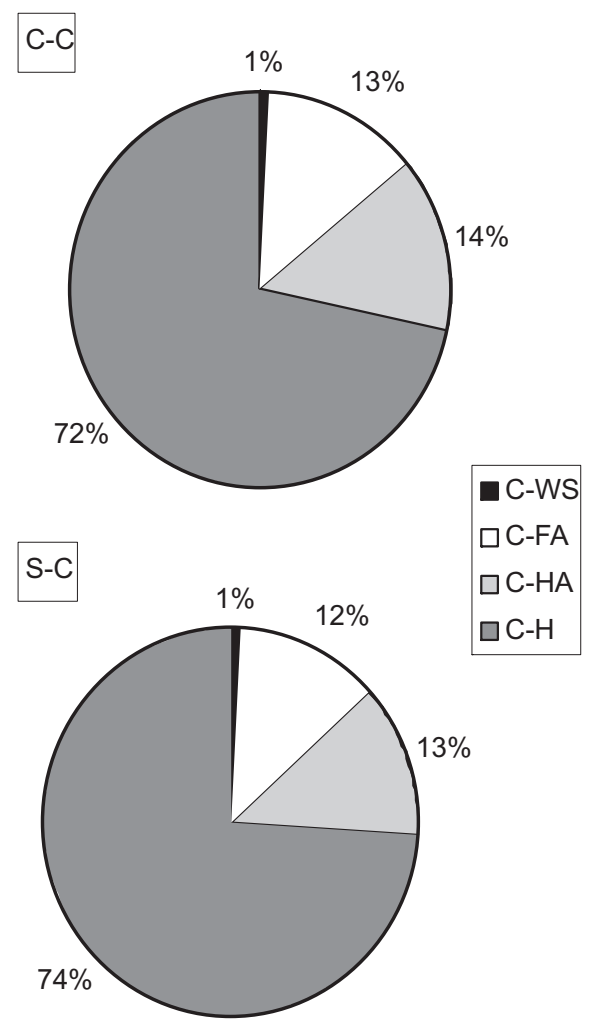

Figure 2 - Mean percentage distribution of $\mathrm{C}$ in the water-soluble (C-WS), humic acids (C-HA), fulvic acids (C-FA), and humin $(\mathrm{C}-\mathrm{H})$ fractions, in corn-corn $(\mathrm{C}-\mathrm{C})$ and soybeancorn (S-C) successions. depth (Stevenson, 1994), because of the greater mobility of compounds in the C-FA fraction in relation to those in the C-HA fraction in the soil (Mendonça \& Rowell, 1994).

There was an interaction between nitrogen sidedressing and crop successions on the C-WS fraction (Table 2). Nitrogen fertilization did not affect the C-WS contents in the soybean-corn succession; the $\mathrm{N}$ effect was quadratic in the corn-corn succession, and the dose equivalent to $176 \mathrm{~kg} \mathrm{ha}^{-1} \mathrm{~N}$ would lead to the maximum theoretical C-WS content of about $0.10 \mathrm{~g} \mathrm{dm}^{-3}$, or the equivalent to $200 \mathrm{~kg} \mathrm{ha}^{-1}$ of this form of organic C (Figure 3). In the soybean-corn succession, the effect of $\mathrm{N}$ doses on the C-WS contents was null, probably due to the contribution of $\mathrm{N}$ from the legume residues. With regard to the mean C-WS contents in the soybean-corn succession, nitrogen fertilization in the corn-corn succession increased C-WS contents at the doses of 120, 180, and $240 \mathrm{~kg} \mathrm{ha}^{-1} \mathrm{~N}$ by about $15 \%, 24 \%$, and $12 \%$, respectively (Figure 3). The results obtained for this organic fraction could be the evidence of a priming effect, that is, theoretically the application of inorganic nitrogen or fresh organic material to the soil stimulates microbial activity and the mineralization of $\mathrm{N}$ forms present in SOM (Jansson \& Persson, 1982). Water-soluble carbon reflects the initial stage of degradation of organic residues in the soil, by which insoluble materials are hydrolyzed to amino acids and soluble sugars (Sousa \& Melo, 2003). However, Duda et al. (1999) previously observed a negative and significant correlation $\left(\mathrm{r}=-0.84^{*}\right)$ between $\mathrm{C}$ forms extracted with water, at a 1:2 soil:extractor ratio and mineralizable carbon, obtained through an incubation assay, indicating that both are controlled by soil biological activity. Sousa \& Melo (2003) found higher nitrogen contents in the SOM water-soluble fraction (N-WS), extracted by a method similar to the one used in the present study, in treatments that included legumes in crop rota-

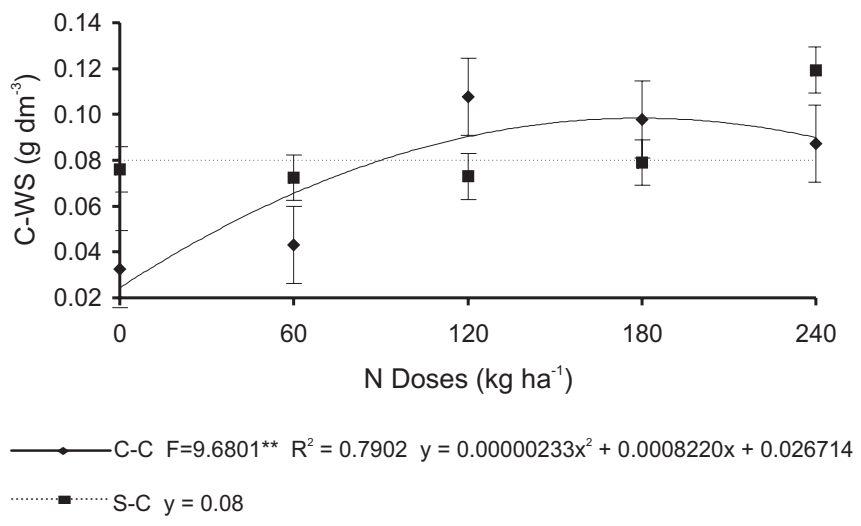

Figure 3 - Carbon in the water-soluble fraction (C-WS) as a function of nitrogen sidedressing, in corn-corn $(\mathrm{C}-\mathrm{C})$ and soybeancorn $(\mathrm{S}-\mathrm{C})$ successions. $* *$ significant at $1 \%$. 
tion. According to the same authors, the compounds in the N-WS fraction are readily assimilable, or can be found in similar forms, and can be used as a source of energy by microorganisms, due to the limiting amount of $\mathrm{C}$ in those plants.

The carbon contents in the C-HS fraction were affected by the interaction between sidedressing $\mathrm{N}$ doses and crop successions (Table 2); the data could not be fitted to polynomial regression models (Figure 4). The undefined trend for the C-HS contents could be associated with the distinct results obtained for the C-HA (Figure 5a) and C-FA (Figure 6) fractions, which make up this fraction.

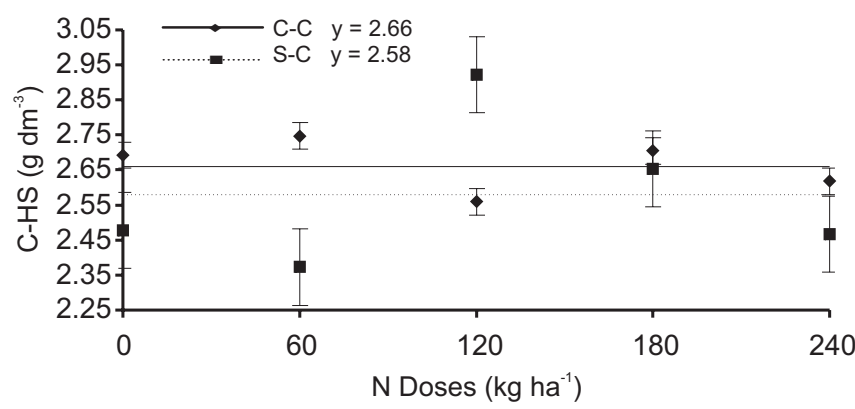

Figure 4 - Carbon in the humic substances fraction (C-HS) as a function of nitrogen sidedressing, in corn-corn (C-C) and soybean-corn (S-C) successions.

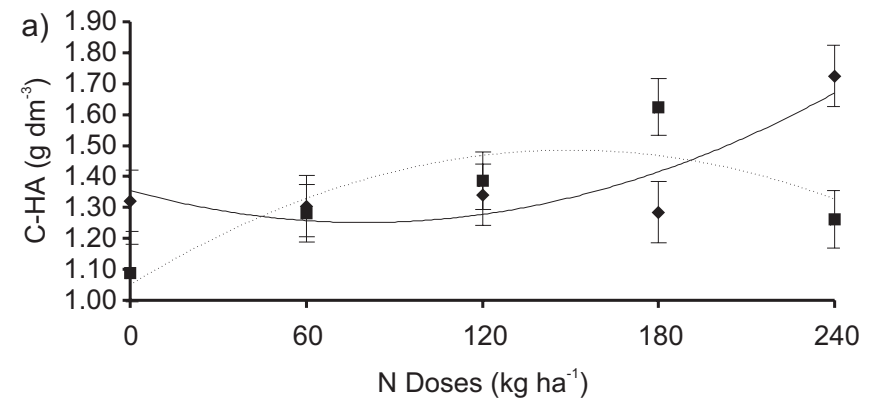

$\longrightarrow C-C F=11.1314^{* *} R^{2}=0.7997 y=0.00001631 x^{2}-0.0025958 x+1.355$

…………..... $F=14.1152^{\star *} R^{2}=0.7513 \quad y=-0.00001969 x^{2}+0.0058803 x+1.047$

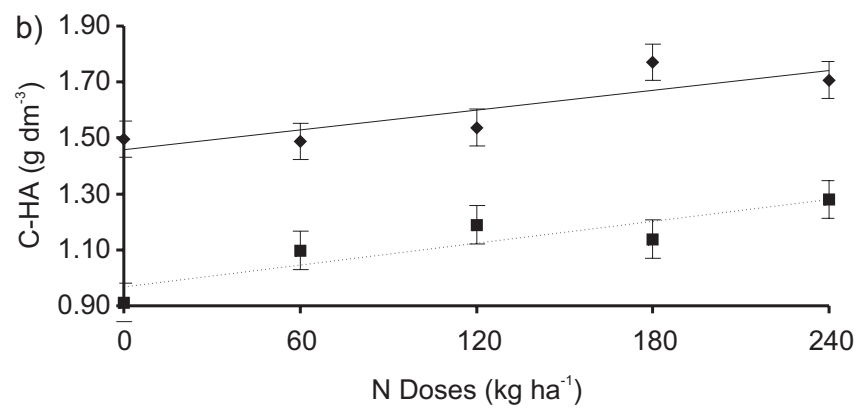

$\longrightarrow 0-20 \mathrm{~cm} \quad F=6.9416^{*} R^{2}=0.7259 y=0.0011625 x+1.461$

………... $20-40 \mathrm{~cm} \quad \mathrm{~F}=31.5392^{\star *} \mathrm{R}^{2}=0.9690 \mathrm{y}=0.0129166 \mathrm{x}+0.9690$

Figure 5 - Carbon in the humic acids fraction (C-HA) as a function of nitrogen sidedressing: a) in corn-corn (C-C) and soybean-corn (S-C) successions, and b) sampling depths. *and ${ }^{* *}$ significant at 5 and $1 \%$, respectively.
Nitrogen sidedressing increased the mean C-HA contents (Table 2). An alternation between crop successions at higher C-HA contents was observed in both successions (Figure 5a). Sousa \& Melo (2003) did not observe differences between C-HA contents at the depth from 0 to $20 \mathrm{~cm}$, in the corn monoculture and soybean rotation production systems. Nascimento et al. (1991) studied soil tillage methods and cropping systems and observed an effect of the interaction of both factors on the C-HA contents in the 15 to $20 \mathrm{~cm}$ depth layer. According to these authors, a combination between a plough/ scarifier and the soybean-corn succession, during four consecutive years, resulted in C-HA contents about $61 \%$ and $23 \%$ higher than in treatments with a heavy harrow and no-till in the same crop succession, respectively, and about $27 \%$ higher than monoculture corn and soil tillage using a scarifier.

For both crop successions, the effect of nitrogen fertilization on C-HA contents was quadratic, and maximum theoretical contents of $1.49 \mathrm{~g} \mathrm{dm}^{-3} \mathrm{C}-\mathrm{HA}$ at a dose of $149 \mathrm{~kg} \mathrm{ha}^{-1} \mathrm{~N}$ in the soybean-corn succession, and of $1.67 \mathrm{~g} \mathrm{dm}^{-3} \mathrm{C}-\mathrm{HA}$ at a dose of $240 \mathrm{~kg} \mathrm{ha}^{-1} \mathrm{~N}$ in the corncorn succession were observed (Figure 5a). The C-HA decrease in the soybean-corn succession after application of a $149 \mathrm{~kg} \mathrm{ha}^{-1} \mathrm{~N}$ dose could be associated with the $\mathrm{N}$ supplied by the soybean crop residues. The urea-released ammonia may be complexed with phenols and quinones, producing compounds with similar characteristics to the compounds of the C-HA fraction (Stevenson, 1994) which in part could explain the obtained results. The peculiar characteristics of phenols and quinones complexed with ammonia include high chemical stability and resistance to microbial decomposition (Nommik \& Vahtras, 1982). The results obtained in the present study are similar to those reported by Tan et al. (1972), who observed a significant correlation $(\mathrm{r}=0.82 * *)$ between total nitrogen contents in the soil and C-HA contents. The CHA content was higher at the 0 to $20 \mathrm{~cm}$ layer, even as a consequence of total organic $\mathrm{C}$ content, and also increased as N doses increased, at both depths (Figure 5b).

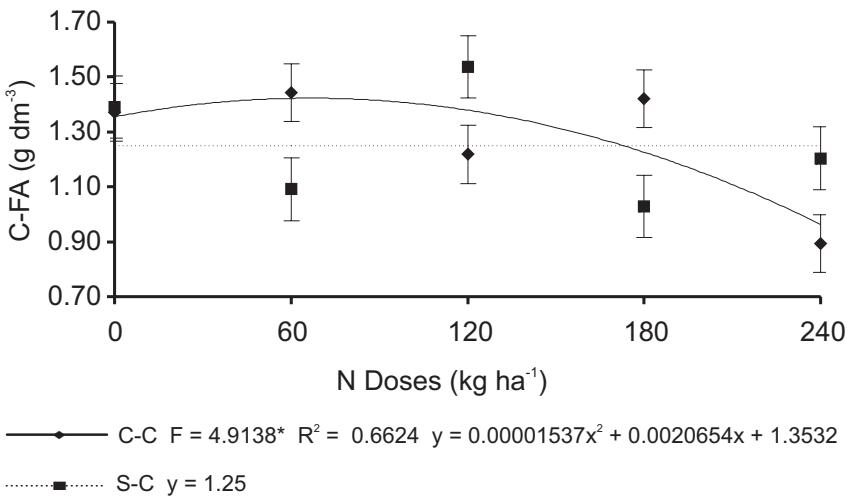

Figure 6 - Carbon in the fulvic acids fraction (C-FA) as a function of nitrogen sidedressing, in corn-corn $(\mathrm{C}-\mathrm{C})$ and soybeancorn $(\mathrm{S}-\mathrm{C})$ successions. ${ }^{* *}$ significant at $1 \%$. 
Nitrogen sidedressing only affected the C-FA contents in the corn-corn succession, where the values best fitted the quadratic regression model (Figure 6). The regression equation allowed us to observe that the maximum theoretical C-FA content, about $1.42 \mathrm{~g} \mathrm{dm}^{-3}$, would be obtained with the application of about $67 \mathrm{~kg} \mathrm{ha}^{-1} \mathrm{~N}$. In the treatment without nitrogen fertilization, the C-FA contents were similar in both crop successions, and nitrogen fertilization promoted great variability in those contents between crop successions, alternating higher and lower contents at each fertilization level (Figure 6). In the no-till system, Sousa \& Melo (2003) observed that corn grown in rotation with soybean presented higher C-FA contents at the depth from 0 to $5 \mathrm{~cm}$, in relation to monoculture corn, while in the conventional system there was no difference between corn production systems. The unstable character of the compounds that make up this fraction, which sometimes present themselves as synthesis precursors, and sometimes as products from the decomposition of compounds that constitute C-HA (Tate III, 1987), and the fact that in the present study the carbohydrates in this fraction were not separated (Stevenson, 1994), may justify why the results did not present a clear trend.

\section{REFERENCES}

BAYER, C.; MIELNICZUK, J. Características químicas do solo afetadas por métodos de preparo e sistemas de cultura. Revista Brasileira de Ciência do Solo, v.21, p.105-112, 1997.

BAYER, C.; MIELNICZUK, J. Dinâmica e função da matéria orgânica. In: SANTOS, G.A.; CAMARGO, F.A.O. Fundamentos da matéria orgânica do solo. Ecossistemas tropicais \& subtropicais. Porto Alegre: Gênesis, 1999. p.9-26.

BAYER, C.; DICK, D.P.; RIBEIRO, G.M.; SCHEUERMANN, K.K. Carbon stocks in organic matter fractions as affected by land use and soil management, with emphasis on no-tillage effect. Ciência Rural, v.32, p.401-406, 2002.

BRODER, M.W.; WAGNER, G.H. Microbial colonization and decomposition of corn, wheat and soybean residue. Soil Science Society of America Journal, v.52, p.112-117, 1988.

BUYANOVSKY, G.A.; WAGNER, G.H. Post-harvest residue input to cropland. Plant and Soil, v.93, p.57-65, 1986.

CADISH, G.; OLIVEIRA, O.C.; CANTARUTTI, R.B.; CARVALHO, E.; URQUIAGA, S. The role of legume quality in soil carbon dynamics in savannah ecosystems. In: BERGSTRÖM, L.; KIRCHMANN, H. Carbon and nutrient dynamics in natural and agricultural ecosystems. Oxon: CAB International, 1998. p.47-70.

DUDA, G.P.; CAMPELLO, E.F.C.; MENDONÇA, E.S.; LOURES, J.L.; DOMINGOS, M. Avaliação de frações da matéria orgânica do solo para caracterização de áreas degradadas. Revista Brasileira de Ciência do Solo, v.23, p.723-728, 1999.

GREGORICH, E.G.; DRURY, C.F.; BALDOCK, J.A. Changes in soil carbon under long-term maize in monoculture and legume-based rotation. Canadian Journal of Soil Science, v.81, p.21-31, 2001.

HATCHER, P.G.; BREGER, I.A.; MACIEL, G.E.; SZVENYI, N.M. Geochemistry of humin. In: AIKEN, R.; MCKNIGHT, D.M.; WERSHAW, R.L. Humic substances in soil, sediment, and water. Geochemistry, isolation and characterization. New York: John Wiley \& Sons, 1985. p.275-302.

HAVLIN, J.L.; KISSEL, D.E.; MADDUX, L.D.; CLAASSEN, M.M.; LONG, J.H. Crop rotation and tillage effects on soil organic carbon and nitrogen. Soil Science Society of America Journal, v.54, p.448-452, 1990.
HAYES, M.H.B.; HIMES, F.L. Nature and properties of humus-mineral complexes. In: HUANG, P.M.; SCHNITZER, M. (Ed.) Interactions of soil minerals with natural organics and microbes. Madison: SSSA, 1986. p.103-158.

JANSSON, S.L.; PERSSON, J. Mineralization and immobilization of soil nitrogen. In: STEVENSON, F.J. (Ed.). Nitrogen in agricultural soils. Madison: ASA; CSSA; SSSA, 1982. p.229-252.

LIANG, B.C.; GREGORICH, E.G.; MacKENZIE, A.F.; SCHNITZER, M.; VORONEY, R.P.; MONREAL, C.M.; BEYAERT, R.P. Retention and turnover of corn residue carbon in some eastern Canadian soils. Soil Science Society of America Journal, v.62, p.1361-1366, 1998.

KIEHL, E.J. Fertilizantes orgânicos. Piracicaba: Ceres, 1985. 492p.

MacCARTHY, P. The principles of humic substances. Soil Science, v.166, p.738-751, 2001.

MENDONÇA, E.S.; ROWELL, D.L. Dinâmica do alumínio e de diferentes frações orgânicas de um latossolo argiloso sob cerrado e soja. Revista Brasileira de Ciência do Solo, v.18, p.295-303, 1994.

MENDONÇA, E.S.; SILVA, I.R. Organic matter and properties of tropical soils. In: INTERNATIONAL MEETING OF IHSS, 12., São Pedro, 2004. Humic substances and soil and water environment; proceedings. São Carlos: Embrapa Instrumentação Agropecuária, 2004. p.607-608.

MIELNICZUK, J. Matéria orgânica e a sustentabilidade de sistemas agrícolas. In: SANTOS, G.A.; CAMARGO, F.A.O. Fundamentos da matéria orgânica do solo. Ecossistemas tropicais \& subtropicais. Porto Alegre: Gênesis, 1999. p.1-8.

NASCIMENTO, E.J.; MOURA FILHO, W.; COSTA, L.M.; CRUZ, J.C.; REGAZZI, A.J. Dinâmica da matéria orgânica em um Latossolo Vermelho-Escuro distrófico, fase cerrado, submetido a diferentes sistemas de manejo. Revista Ceres, v.28, p.513-521, 1991.

NOMMIK, H.; VAHTRAS, K. Retention and fixation of ammonium and ammonia in soils. In: STEVENSON, F.J. (Ed.) Nitrogen in agricultural soils. Madison: ASA; CSSA; SSSA, 1982. p.123-171.

OLIVEIRA, J.B.; PRADO, H. Levantamento pedológico semi detalhado do Estado de São Paulo: quadrícula de Ribeirão Preto. Campinas: EMBRAPA; IAC, 1987. 133p. (Boletim Científico, 7).

RAIJ, B. van; QUAGGIO, J.A.; CANTARELLA, H.; FERREIRA, M.E.; LOPES, A.S.; BATAGLIA, O.C. Análise química do solo para fins de fertilidade. Campinas: Fundação Cargill, 1987. 170p.

RICE, J.A. Humin. Soil Science, v.166, p.848-857, 2001.

SOUSA, W.J.O.; MELO, W.J. Matéria orgânica de um Latossolo submetido a diferentes sistemas de produção de milho. Revista Brasileira de Ciência do Solo, v.27, p.1113-1122, 2003.

STEVENSON, F.J. Humus chemistry: genesis, composition, reactions. 2.ed. New York: John Willey \& Sons, 1994. 512p.

TAN, K.H.; BEATY, E.R.; McCREERY, R.A.; POWELL, J.D. Humic-fulvic acid content in soils as related to ley clipping management and fertilization. Soil Science Society of America Proceedings, v.36, p.565$567,1972$.

TATE III, R.L. Soil organic matter - Biological and ecological effects. New York: John Wiley \& Sons, 1987. 340p.

VARGAS, M.A.T.; HUNGRIA, M. Fixação biológica do nitrogênio na cultura da soja. In: VARGAS, M.A.T.; HUNGRIA, M. (Ed.) Biologia dos solos dos cerrados. Planaltina: EMBRAPA; CPAC, 1997. p.295360.

VARVEL, G.E. Rotation and nitrogen fertilization effects on changes in soil carbon and nitrogen. Agronomy Journal, v.86, p.319-325, 1994.

VOLKOFF, B.; FLEXOR, J.M.; SANTA ISABEL, L.; SANTA ISABEL, M. Natureza do húmus nos latossolos distróficos da Bahia. Revista Brasileira de Ciência do Solo, v.2, p.59-63, 1978.

YAGI, R.; FERREIRA, M.E.; CRUZ, M.C.P.; BARBOSA, J.C. Organic matter fractions and soil fertility under the influence of liming, vermicompost and cattle manure. Scientia Agricola, v.60, p.549-557, 2003.

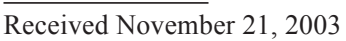

Accepted June 03, 2005 